\title{
THEMING DISCURSE IN VILLAGE DEVELPOMENT
}

Ingrida KAZLAUSKIENE், Business and Rural Development Management Institute, Vytautas Magnus University. K. Donelaičio g. 58, LT-44248 Kaunas, Lithuania, ingrida.kazlauskiene@vdu.lt (corresponding author)

Vilma ATKOČIŪNIENĖ, Prof. $d r$., Business and Rural Development Management Institute, Vytautas Magnus University. K. Donelaičio g. 58, LT-44248 Kaunas, Lithuania, vilma.atkociuniene@gmail.com

\begin{abstract}
The issues of the development of thematic villages are mostly investigated in Poland, Austria, Lithuania. Village development theming is usually defined as a strategy or model. It acts as a vehicle for village renewal, enabling even small villages to develop successfully in the age of globalization. An experiential marketing strategy guides village development towards sustainability and helps to ensure integration between village environmental, economic and social development dimensions. Thematic villages play a heuristic role, they "push" locals and customers out of established spaces, village storytelling schemes, and encourage the search for alternative life, behavior and business models. This research aim was achieved: to determine the characteristics of the village theming development: thematic space, integrated (complex) consumption, co-creation, recreation, interests (needs), experience. Thematic analysis, collation and other methods of scientific literature were applied. Representatives of the various stakeholders must be involved in the village development theming characteristics package planning, management and control processes. There is a two-way communication between the development of various thematic objects in economic, social and environmental terms and the creation of a thematic space which must serve not only the interests of the visitors but also the inhabitants.
\end{abstract}

Keywords: thematic village, theming, village development.

\section{INTRODUCTION}

There are many, sometimes conflicting, incentives - local, national, regional and global for conservation and usage of rural areas in the 21 st century second decade. Contemporary villages intertwine different and ambiguous motifs turning them into goods for "internal needs" (increase in land fund and real estate prices, development of primary agricultural production, reproduction of consumption-promoting spaces, etc.) and "external needs" (national, regional and even international competitiveness in attracting population and investment, developing their image for the tourism market, developing the heritage products, services sector and infrastructure, etc.).

Rural areas are going through a period of change, when more active rural people are looking for new ways to steer rural development towards sustainability and to ensure the integration of environmental, economic and social development dimensions. Increasingly, village residents are active participants in the value chain of local products, they are choosing non-agricultural activities and focusing on rural tourism.

One of this type activity - the theming village development, which, according to researchers who analyzed thematic villages (Vaznonis and Čiūtaitè, 2010; Atkočiūnienè and Vaišnoraitè, 2012; Dombrowicz, 2013; Kloczko-Gajewska, 2013, 2014; 2018; Szcesna and Welosowska, 2015; Idziak, Majewski and Zmyslony, 2015; Wachter and Wytrzens, 2016; Atkočiūnienè and Kaminatė, 2017), creates conditions for proactive village development.

Vaznonis and Čiūtaite (2010) revealed the positive influence of theming on the Lithuania rural sustainable development and noted that thematic villages are a community business space that promotes the entrepreneurship of local people and enhances the economic competitiveness of the area. According to Dombrowicz (2013), the creation of a thematic village in Poland enables the local community to generate income from tourism and to strengthen the local economy. These research findings are also supported by Idziak, Majewski and Zmyslony (2015), who further point out that theming acts as a means of village renewal, enabling even small Polish villages to thrive in the age of globalization. According to the authors, village theming should be treated as an adapted vision of rural development. Szcesna and Welosowska, (2015) also mentions that the theming of village development is one of the most appropriate measures to promote the development of rural tourism in Polish regions, providing opportunities to solve economic, unemployment and emigration problems. Kloczko-Gajewska (2013), is researching thematic villages in Poland, she quotes Czapiewska, (2012) and states that village theming brings not only economic value to the local population but also social value, which is manifested by opportunities to realize themselves in favorite activities, socialize and cooperate. In 2014, this researcher identified that thematic village is a social innovation that helps to solve certain rural problems (mostly of a social nature or having a significant social impact). Village theming also helps to improve daily life in the countryside, create job opportunities, activate the local community to express their interests, find a group of people who want to work together, learn new things and new look at old things, and have opportunities for self-actualization and income. Kloczko-Gajewska

Copyright (c) 2019 The Authors. Published by Vytautas Magnus University. This is an open-access article distributed under the terms of the Creative Commons Attribution License (CC-BY 4.0), which permits unrestricted use, distribution, and reproduction in any medium, provided the original author and source are credited. 
(2018) identified that the creation of thematic villages is a strategy for village development, which helps to rebuild social capital in the countryside, learn and disseminate knowledge, combat with unemployment and demographic decline. The positive influence of thematic villages on Lithuanian villages social development is also emphasized by Atkočiūnienè and Vaikšnoraitė (2012). In their opinion, the establishment of a thematic village provides a strategic breakthrough in the development of the area, through a positive impact on the local inhabitants culture, strengthens their cooperation, solidarity and responsibility, and promotes innovative decision-making. Wachter and Wytrzens (2016), in a study of Austrian thematic villages, found that theming enhances communality and activeness of the inhabitant, because in development interested stakeholders are much more actively involved in associations and other organizations, who operating in their villages and elsewhere. According to Atkočiūnienè and Kaminaite (2017), a thematic village strategy is a tool to manage the development of the territory and develop its value by creating and selling goods, services and carrying out integrated activities. According to the authors, in the thematic villages authentic enivironmental tourists and locals can entertain. The thematic village strategy also generates public benefits that can enhance the vitality of the villages, integrate economic and social activities, and improve the image of the village. Kloczko-Gajewska (2018) also notes that thematic villages establishment encourage the community to take care of improving the village environment, infrastructure and adapting it to the theme.

Research focusing on thematic villages reveals the concept of thematic villages and indicates the positive impact of theming on village and regional development. However, the design and implementation of local development strategies still lacks science-based thematic characteristics that should be evaluated and developed in order to achieve sustainable village development.

The scientific problem is formulated by the question: What village develpoment theming characteristics determine village development?

The aim of the study: to determine village development theming characteristics.

\section{RESEARCH METHODS}

No research has been found to analyze the thematic characteristics that promote rural development. Therefore, a thematic analysis has been carried out of the research analyzing the influence of theming on the development of various other thematic objects. The research assumes that the thematic characteristics that influence the development of other thematic objects have a positive influence on the development of thematic villages as well.

In the first phase, meaningful ideas (sentences and paragraphs) were selected from a selection of scientific publications on the subjecting of different objects, which can be contextualized and interpreted to identify the characteristics of the subjecting that promote the development of thematic objects. The theming of theese objects was analyzed: services and goods (Stromberg, 2015); cities (Frenkel and Walton, 2000); cruises (Astrom, 2017); tourist routes (Pikkemat, Peters, Boksberger and Secco, 2009); parks (Wong and Cheung, 1999; Torres, Milman, Park, 2018); restaurants (Meng and Choi, 2018; Sinha, Chaudhuri, Fowler, and Mazumdar, 2018); hotels (Hung, Wang and Tang, 2015); villages (Vaznonis and Čiutaitè, 2010; Atkočiūnienè and Vaišnoraitė, 2012; Dombrowicz, 2013; KloczkoGajewska, 2013, 2014, 2018; Szcesna and Welosowska, 2015; Idziak, Majewski and Zmyslony, 2015; Wachter and Wytrzensiene, 2016; Atkočiūnienè and Kaminatè, 2017).

In the second stage, meaningful concepts were selected from these meaningful ideas, which reveal the components of the theming characteristics that determine the development of the thematic object.

In the third stage, with the help of the thematic map, the meaningful concepts were grouped. The groups of meaningful concepts helped to reveal the characteristics of theming that promote the development of the thematic object.

\section{RESEARCH RESULTS}

After the thematic analysis, the characteristics of theming that provide value for the development of the thematic object have been identified: thematic space, co-creation, integrated (complex) consumption, recreation, interests (needs), experience. The following thematic characteristics that promote the development of thematic objects are discussed below.

Thematic space. Theming helps interested actors in the development of thematic objects to create a distinctive thematic atmosphere. It intrigues and attracts visitors, because it takes them to a different period and space, gives them exotics, creates the illusion of realizing fantasies. According to Wong and Cheung (1999), the theme is revealed through careful planning, which includes interior and other environmental components, staff clothing, customer focus, goods, services, and so on. According to the authors, the thematic object allows its visitors to escape into the fantasy world. According to Stromberg (2015), the thematic concept is a narrative space. The purpose of thematic objects is to create an atmosphere of another world. This view is shared by Sinha, Chaudhuri, Fowler, and Mazumdar (2018), who argue that thematic objects - symbolic simulation fields that represent the imagination and desires of clients - give clients the illusion of moving to another time and space. According to the authors, the theme must be authentic in order to convince the visitors. This is corroborated by Pikkemaat, Peters, Boksberger and Secco (2009) who argue that the theme is the most important tool for ensuring the authenticity and consistency of the space. Torres, Milman, Park (2018) states that thematic objects are a form of entertainment designed to create a fantasy that is reminiscent of another place and time. The theme space is created by the harmony, coherence and consistency of the theme itself. According to Stromberg (2015), theming 
is used to create a holistic and cohesive place for the consumption of goods and services in terms of space, culture and social environment. According to Astrom (2017), in order for a client to recognize a theme, it must be holistically applied throughout the material and social context of the thematic object environment. According to Sinha, Chaudhuri, Fowler, and Mazumdar (2018), thematic spaces create a market phenomenon that manifests itself through the rich, sophisticated visual image which is addressed to those who participate in activities in such thematic spaces.

Integrated (complex) consumption. Theming promotes integrated consumption, where visitors derive value not only from the goods and services which are sold in thematic objects, but also from the theme, the environment, the narratives (Stromberg, 2015). Thematic objects are designed to integrate theme-based infrastructure and experience (Hung, Wang and Tang, 2015). According to Sinha, Chaudhuri, Fowler and Mazumdar (2018), theming requires integration of production and consumption. In order to give visitors a sense of the theme, it is necessary to involve them in the production processes, which thus become usable. Thematic objects offer a full-service that can create a themed experience through accommodation, recreation, entertainment, retail and catering. The theme helps to combine different services and goods into one entirety. To get a feel for the theme, clients use the full package offered to them: participating in theme-related educational activities, eating theme-related meals in restaurants with theme-themed interiors, staying in themed hotels, theme-oriented actors interacting with clients with theme-specific mannerisms and narrates thematic narratives. Visitors to thematic objects consume a complex package of thematic activities, services and goods, theme, environment and narratives.

Co-creation. Thematic space in thematic objects enables clients to participate in various activities. Stromberg (2015) states that a thematic concept is a narrative space that creates opportunities for human interaction in a commercial context. According to the author, theming creates not one-sided relationship between thematic service providers and customers. According to Astrom (2017), a theme provides opportunities for visitors to visit an exclusive thematic space and for actors, who are interested in developing thematic objects to create a thematic environment and maintenance coherence between interiors, services, services, goods, activities, narratives, and more. Collaboration - creating value through interaction between organization and consumer (Gebauer, Johnson, and Enquist, 2010; Ramaswamy and Gouillart, 2010; Grönroos, 2012). According to Scriven (2012), co-creation is a multidimensional consumption process where providers and users interact for maximum benefit. It can be assumed that theming encourages the co-creation of visitors and actors, who are interested in the development of thematic objects. Meng and Choi (2018) also argue that the thematic environment helps tell the story in which the visitor is involved and thus adds more value to the thematic entertainments. If visitors to a thematic site want to experience the impressions offered by the theme, they must actively participate in the proposed activities and interact with the actors involved in the development of the thematic objects and other clients.

Recreation. The theming is related to recreation, commerce and leisure. Thematic environments are created by entrepreneurs to attract customers to extraordinary leisure and pleasure venues (Stronberg, 2015). Frenkel and Walton (2000) observed that after the recession of the Second World War, many resource-based rural areas began to implement tourism development strategies. Tourism is one of the forms of recreation. Wong and Cheung (1999) consider the popularity of thematic leisure activities to be evident as more and more new tourist attractions for thematic leisure appear in recent years. Sinha, Chaudhuri, Fowler and Mazumdar (2018) also argue that theming creates spaces where visitors can not only spend their leisure time but also experience certain cultures and immerse themselves in them. Torres, Milman, Park (2018) notes that theme parks and amusements provide leisure and recreation services not only to tourists but also to locals. According to scientists who have studied the phenomenon of theming, it can be said that it helps to create spaces for leisure, recreation, and recreation. Visitors who want to relax, spend their leisure time or have fun, choose the thematic objects of interest to them.

Interests (needs). Researchers who analyze the phenomenon of theming say that theming offers visitors the opportunity to meet their own interests. The themes of thematic objects tend to focus not only on recreation but also on various areas of interest or hobbies. Mostly thematic environments are related to geography, history, popular culture, social organizations (Stronberg, 2015). Citing Alan Bryman's (2004) taxonomy, Stronberg (2015) states that the most common motifs and sources for thematic topics are various places, periods, sports, music, cinema, fashion, goods, architecture, nature, literature, morals, and philosophy. Also, one theme can cover multiple motifs at once. According to Pikkemaat, Peters, Boksberger, and Secco (2009), a topic that is in the interest of a visitor strongly influences the decisions of potential visitors to visit a particular place. Often culture, symbols, history and myths form the basis for the development of the theme. According to Wong and Cheung (1999), thematic tourism is gaining popularity because interest in a particular subject or area, rather than traditional motives such as idyllic landscapes and climate, encourages travel. Contemporary thematic objects of interest often feature picturesque landscapes that are associated with stories, books, plays and movies (Torres, Milman, Park, 2018). It can be assumed that theming provides opportunities for visitors to meet their hobbies, find out more about their areas of interest, and feel them.

Experience. Modern consumers have a wide range of features, they are no longer limited to goods and services, but want to gain experience with them. The theming is one of the main methods of creating experiential consumption opportunities (Stromberg (2015; Wong and Cheung, 1999). Visitors expect exclusive experiences at themed objects (Sinha, Chaudhuri, Fowler and Mazumdar, 2018). Experimental consumption, which is usually associated with theme parks, restaurants, museums are rapidly gaining popularity in tourism and accommodation (Meng and Choi, 2018). Hung, Wang, and Tang, (2015) state that the purpose of religious hotels is to provide clients with a religious experience through thematic infrastructure. According to them, the popularity of thematic objects is not only stimulated by competitive struggles, but also because of the growing popularity of thematic tourism. Astrom (2017) found that the purpose of thematic objects is to create an unforgettable impression on clients, the theme at the level of client perception and 
interpretation reveals what its creator wants the audience to understand and remember. This is in line with the concept of experience developed by Pine and Gilmore (2011), which states that the theme is what the customer remembers. In the last decade, tourism services have been increasingly focused on creating experiences for tourists, rather than simply providing goods and services to tourists. According to Frenkel and Walton (2000), since about 1980 the since the mid1990s, adventure tourism, eco-tourism, heritage tourism and cultural events have become increasingly popular, and a whole new field of experiential tourism has emerged.

\section{DISCUSSION}

After summarizing and linking the distinguished characteristics, a model of the influence of theming characteristics on village development was created (Fig. 1).

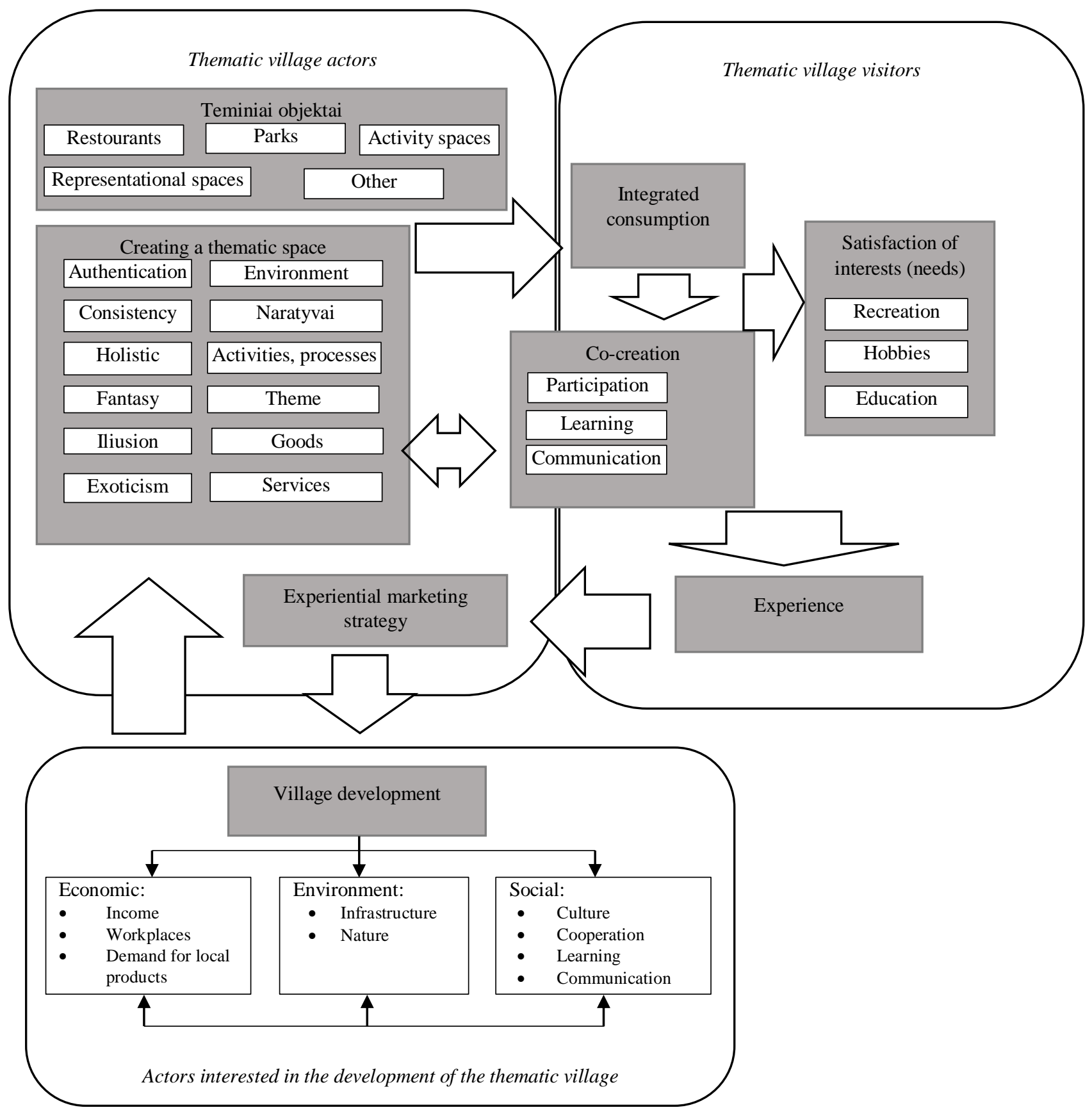

Figure 1 Model of the influence of theming characteristics on village development

A thematic village is a thematic object in which is a reciprocal link between various thematic (restaurants, parks, exhibitions, activities and representation spaces, etc.) development in economic, social and environmental aspects. A theme village can consist of several thematic objects. The model reveals that actors, who are interested in the development of thematic villages create an authentic, harmonious, holistic, creative theme space that integrates fantasy, illusion and exotic. Thematic objects visitors use components of the thematic space in an integrated (complex) way: the theme environment, narratives, activities and processes, goods and services. Integrated consumption involves co-creation, which 
creates opportunities to meet visitors' interests (needs) for recreation and hobbies, and to gain exceptional experiences. Providing experience and good emotions to visitors is a key theming goal. As a product, a thematic village reaches the hearts and minds of consumers, providing a more competitive edge. Thus, the experience created by thematic objects to visitors allows actors to carry out an experiential marketing strategy that helps to attract and develop visitor loyalty. Thematic facility activities create demand for local products, jobs and incomes for thematic village actors and community. Theming provide opportunities for collaboration and communication, cultural development and learning, promote infrastructure improvements, and nurture nature.

Authors who analyzed thematic villages (Atkočiūnienè and Vaikšnoraite, 2012; Dombrowicz, 2013; KloczkoGajewska, 2013, 2014, 2018; Szcesna and Welosowska, 2015, Idziak, Majewski and Zmyslony, 2015; Wachter and Wytrzens, 2016; Atkočiūnienè and Kaminaitè ) do not identify the theming characteristics that influence the development of the thematic village. However, it is possible to evaluate the latent meaning of certain statements in the analyzed scientific publications about thematic villages and to assume that their development is driven by similar characteristics as other thematic objects. Based on the results of this study, it is planned to conduct an empirical study in thematic villages to determine the expression of distinguished theming characteristics in thematic villages.

In thematic villages, as in other thematic objects, an integral thematic space is being created. Atkočiūnienè and Kaminaite (2017) argue that in theme villages visitors and locals can entertain in an authentic environment. KloczkoGajewska $(2013,2015,2018)$, found that the establishment of a thematic village encourages the community to take care of improving and adapting the village environment and infrastructure to the theme.

Provision of thematic village services is not possible without interaction and cooperation between the service provider (actor interested in thematic village development) and the service recipient (visitor), because during the provision of these services there is active communication, knowledge exchange, learning, service development. Both the service provider and the visitor of the thematic village need to get involved and empathize with the co-creative processes in the thematic village. Careful listening, interest, and sincere participation in thematic village activities provide opportunities for visitors to gain experiences and impressions.

Visitors to thematic villages consume not only goods and services, but also the theme itself, the environment, the narratives activities offered by the thematic village actors. All this becomes a commodity and is used in an integrated (complex) way. In Thematic villages, as in other thematic objects, integrated consumption takes place because there is the exclusive theme that attracts visitors to the thematic village, encourages them to purchase themed goods or services, participate in educational activities, enjoy the thematic village environment, areas and nature.

In introducing the concept of thematic villages, Kloczko-Gajewska (2013) points out that thematic villages usually offer tourists a variety of themed activities. These are mainly services related to the chosen theme: various types of workshops (eg. handicrafts or traditional dishes), local games, lessons and shows, holidays, tours, games, competitions, educational programs. Other authors point out that themes in thematic villages are often related to culture, history, heritage or even innovation. Most definitions of thematic villages emphasize that thematic villages should be created on the basis of old traditions, that they should attract tourists with traditional crafts, ceremonies and products. Initially, the thematic villages were only concerned with preserving ancient culture and heritage. Later, the authors (Kloczko-Gajewska, 2014; Atkočiūnienè and Kaminaitè, 2017) began to encourage the founders of thematic villages to look at traditional things in a new way, and the concepts of thematic villages introduced new concepts of innovation. It was realized that the thematic village could offer not only services and products related to the old culture, but also new and unique ones. Themes and activities offered by thematic villages, as well as other thematic objects, are related to visitors' interests (needs), which is one of the factors that encourage visitors to visit. Opportunities to satisfy your curiosity, learn and try new things attract visitors to thematic villages.

Analyzed scientific publications mention that in thematic villages visitors have opportunities to participate in festivals, educational activities, entertain, listen to different stories, play. Thus, it can be assumed that the proposed thematic activities, thematic environment, and nature in the thematic villages provide opportunities for visitors to meet their recreational needs.

The creation of experience in the analyzed scientific publications on thematic villages is also not mentioned. However, it can be assumed that in thematic villages, as in other thematic objects, visitors gain experience through thematic environments, narratives, activities and processes. Considering the services provided by thematic villages and their aspirations to become part of rural tourism, it can be said that they, like other thematic tourism objects, provide visitors not only with goods and services, but also with experience. Experience for both visitors and service providers is created through thematic environments, visitor interest topics, recreational opportunities, and co-creation and integrated consumption processes.

The theme gives visitors an experience that makes them feel as if they are in another world, another culture, another place, another time or even a fantasy. The harmonious and intriguing environment, the co-creativity and the integrated consumption of thematic objects give visitors experience through impressions, sensations, stimuli, and help to understand the essence of the theme. According to Schmitt and Rogers (2008), who are pioneers of the concept of experiential marketing, experience is "private events that respond to certain stimuli. Experiences are the result of direct observation or involvement in events, which can be both realistic, coveted and virtual".

Frenkel and Walton (2000) state that theming is part of a small-town marketing strategy. According to these authors, in order to attract tourists, the topic must not only be interesting and enticing, but also from the active marketing support activites must be applied. In the authors' opinion, the application of a thematic strategy influences the transformation of the small cities through emulation (replication of other sites), authenticity, visual exclusivity, and 
location support. However, due to the underdeveloped marketing of the thematic village, promoters have a weak ability to publicize their educational programs, local products and services (Atkočiūnienè and Kaminaitė, 2017). Competitive struggle in the market involves not only businesses, public organizations and non-profit organizations, but localities are also increasingly competing (Atkočiūnienè and Pocevičiūtè, 2010). Location marketing gives for the area greater opportunities to intensify its competitive position at various levels, helps local actors to answer the question of how a location can become more attractive to residents, investors, and tourists. The purpose of developing location marketing is to promote or create a positive view of a particular area or region.

\section{CONCLUSIONS}

1. Thematic villages play a heuristic role by "pushing" inhabitants and visitors out of steady spaces, village storytelling schemes, and encouraging them to search for alternative life, behavior and business models.

2. Theming is an experiential marketing strategy - marketing decisions and actions that include object's distinctiveness, identity, theme environment and customer communication creating and managing. All of this must be based on the visitor experience of a particular theme: emotional, sensory, social, and others, in order to create mutual value, both for the visitor and the actor interested in developing the thematic object. Through marketing strategy, actors interested in developing thematic objects seek to attract visitors and gain a competitive advantage in the market.

3. Thematic villages, as models or strategies, are social innovation because they provide inhabitants with opportunities to meet their own and visitors social needs, express village public and personal interests, and find a group of people who are willing to collaborate on a village development theming idea.

4. Theming promotes a co-creation of visitors, actors and other stakeholders who are interested in the development of thematic objects. Co-creation enables them to gain a better understanding of the theme. It also meets their communication, engagement and learning needs. In order for the thematic village visitors to recognize the theme, it must be holistically applied throughout the material and social environment of the thematic objects. A thematic village is a thematic object, which can consist of several thematic objects that must be developed in an integrated way.

5. Theming (for actors, who are interested in the development of thematic objects) enables the creation of an authentic, harmonious and holistic integral thematic space of fantasy, illusion, exotics, which includes certain components theme, environment, events, narratives, activities and processes, goods and services. Theming creates a special relationship between thematic object functions and social meaning. The structuring of village space is the structuring of relationships between people.

6. Theming of village development enables not only problem solving but also proactive actions. Theming of village development is not a process in itself, it must be managed by village community and other stakeholders (farmers, entrepreneurs, consultants, local authorities).

7. The theming of the village development must meet not only the needs of visitors but also the present and future everyday life and development needs of the village inhabitants. The interests of the village inhabitants must be a primary consideration in the planning of the theming. It is necessary to ensure that the components of village development do not become only the decor of the thematic space or a part of integrated consumption. It should be borne in mind that visitors spend only a few hours here and residents spend here all their lifetime. Therefore, the combination of the implemented theming characteristics and the intensity of development must primarily be in line with the lifestyle of the inhabitants, with the level of their involvement in the thematic village activities, the identity and the vision of village development.

8. Theming village development creates value for visitors and inhabitants through the involvement of various stakeholders in the thematic process and ensuring the balanced consume of village resources for the development of theming characteristics.

\section{REFERENCES}

1. Astrom J. K. 2017. Theme factors that drive the tourist customer experience. International Journal of Culture, Tourism and Hospitality Research, Vol. 11, Issue 2, pp. 125-141. https://doi.org/10.1108/IJCTHR-07-2015-0070

2. Atkočiūnienė V., Kaminaitė G. 2017. Lietuvos teminių kaimų vystymosi varomosios jègos stiprinant jų gyvybingumą. Vadybos mokslas ir studijos- kaimo verslu ir ju infrastruktūros plètrai, Vol. $_{39}$ Iss. 2, pp. $139-147$. https://doi.org/10.15544/mts.2017.10 (In Lithuanuan)

3. Atkočiūnienė,V., Pocevičiūtè,D. 2010. Kaimo vietovių rinkodaros komplekso formavimo principai. Vadyba: mokslo tiriamieji darbai. Vol. 1, Iss. 17, pp. 187-193. https://www.ltvk.lt/file/zurnalai/Vadyba_2010(17).pdf (In Lithuanuan)

4. Atkočiūnienė V., Vaišnoraitė R. 2012. Kaimiškujų vietovių vystymo strateginio proveržio sąlygos: Dargužių kaimo atvejis. Žemés ūkio mokslai, Vol. 19, Iss. 3, pp.180-191. https://doi.org/10.6001/zemesukiomokslai.v19i3.2505 (In Lithuanuan)

5. Bryman A., 2004. The Disneyization of Society. London: Sage.

6. Czapiewska G. 2012. Thematic villages as a way of economic and social activation of the region. Studia i Materiaty. In: Miscellanea Oeconomicae, Vol. 1, pp. 109-123.

7. Dombrowicz M. 2013. Chrystkowo - A Thematic Tourist Village, is a new offer for tourism. Journal of Health Sciences, Vol. 3, Issue 15, pp. 297-301. ISSN 1429-9623 / 2300-665X.

8. Frenkel S., Walton J. 2000. Bavarian Leavenworth and the symbolic economy of a theme town. Geographical Review, Vol. 90, Iss. 4, pp. 559-584. https://doi.org/10.1111/j.1931-0846.2000.tb00354.X 
9. Gebauer H., Johnson M., Enquist B. 2010. Value co-creation as a determinant of success in public transport services: a study of the Swiss Federal Railway operator (SBB). Managing Service Quality: An International Journal, Vol. 20, Iss. 6, pp. 511530. https://doi.org/10.1108/09604521011092866

10. Grönroos C. 2012. Conceptualising value co-creation: a journey to the 1970s and back to the future. Journal of Marketing Management, No. 28, Vol. 13, Iss. 14, pp.1520-1534. https://doi.org/10.1080/0267257X.2012.737357

11. Hung K., Wang S., Tan, Ch. 2015. Understanding the normative expectations of customers toward Buddhism-themed hotels: A revisit of service quality. International Journal of Contemporary Hospitality Management, Vol. 27, Iss. 7, pp.1409-1441, https://doi.org/10.1108/IJCHM-12-2012-0264

12. Idziak W., Majewski, J., Zmyslony P. 2015. Community participation in sustainable rural tourism experience creation: a longterm appraisal and lessons from a thematic villages project in Poland. Journal of Sustainable Tourism, No. 23, Vol. 8, Iss. 9, pp. 1341-1362. https://doi.org/10.1080/09669582.2015.1019513

13. Kloczko-Gajewska A. 2013. General characteristics of thematic Villages in Poland. Visegrad Journal on Bioeconomy and Sustainable Development, Vol. 2, pp. 60-63. https://doi.org/10.2478/vjbsd-2013-0012

14. Kloczko-Gajewska, A. 2014. Can we treat thematic villages as social innovations? Journal of Central European Green Innovation, Vol. 2, Iss. 3, pp.49-59.

15. Kloczko-Gajewska A., Markiewic, O. 2018. The Spread of Thematic Village Idea in Poland. Wieś i Rolnictwo, Vol. 3, Iss. 180, pp.191-207. DOI: 10.7366/wir032018/09

16. Meng B., Choi K. 2018. An investigation on customer revisit intention to theme restaurants: The role of servicescape and authentic perception. International Journal of Contemporary Hospitality Management, Vol. 30, Iss. 3, pp.1646-1662. https://doi.org/10.1108/IJCHM-11-2016-0630

17. Pikkemaat B., Peters M., Boksberger P., Secco M. 2009. The Staging of Experiences in Wine Tourism. Journal of Hospitality Marketing and Management, Vol. 18, Iss. 2, pp. 237-253. https://doi.org/10.1080/19368620802594110

18. Pine B.J., Gilmore J.H. 2011. The Experience Economy, Harvard Business Press, Boston, MA.

19. Ramaswamy V., Gouillart F. 2010. The Power of Co-Creation, Free Press. New York, NY.

20. Scriven P. 2012. International focus: public service co-production around the world. Guardian News and Media Limited.

21. Schmitt, B. H., Rogers, D. L. 2008. Handbook on Brand and Experience Management. Great Britain: MPG Books Ltd. https://www.academia.edu/21878510/_Bernd_H._Schmitt_David_L._Rogers_Handbook_on_br_Book_ZZ_org

22. Sinha N., Chaudhuri H. R., Fowler J. G., Mazumdar S. 2018.Marketmediated authenticity in culturally themed culinary space. Qualitative Market Research: An International Journal Vol. 21, Iss. 3, pp. 353-374. https://doi.org/10.1108/QMR-07-2016$\underline{0059}$

23. Stromberg p. 2015. Theming. The Wiley Blackwell Encyclopedia of Consumption and Consumer Studies, First Edition, JohnWiley and Sons, Ltd. https://doi.org/10.1002/9781118989463.wbeccs228

24. Szcesna J., Welosowska M. 2015. Tourism as a Chance for Develpoment of Peripheral rural areas within the easten part of Lubenskie voivodship. Barometr Regionalny, Vol. 13, Iss. 1, pp. 85-90. http://br.wszia.edu.pl/zeszyty/pdfs/br39 12szczesna.pdf

25. Torres E. N., Milman A., Park S. 2018. Delighted or outraged? Uncovering key drivers of exceedingly positive and negative theme park guest experiences. Journal of Hospitality and Tourism Insights. Vol. 1, Iss. 1, pp. $65-85$. https://doi.org/10.1108/JHTI-10-2017-0011

26. Vaznonis V., Čiūtaitè D. 2010. Links between rural economic competitiveness and local entrepreneurship. Management science and studies for the development of rural businesses and their infrastructure, Vol. 22, Iss. 3, pp. 1-9. http://vadyba.asu.1t/22/181.pdf

27. Wachter M., Wytrzens K. H. 2016. The impact of a local thematic focus on community building activities in rural villages. Erschienen im Jahrbuch der Österreichischen Gesellschaft für Agrarökonomie, Vol. 25, pp. 149-158, http://oega.boku.ac.at.

28. Wong K., Cheung P., 1999. Strategic theming in theme park marketing. Journal of Vacation Marketing, Vol. 5, Iss. 4, pp. $319-332$. https://doi.org/10.1177/135676679900500402 